\section{Sveto Purić ${ }^{1}$}

University of Kragujevac,

Faculty of Law, Kragujevac, Serbia

\section{Savić Božić Dijana ${ }^{2}$}

Secretary of the Court of General Jurisdiction in Bijeljina,

Bosna and Herzegovina
SCIENTIFIC REVIEW ARTICLE doi:10.5937/ekonomika1603079P

Received: Jun 06, 2016

Accepted: August 31, 2016

\title{
DIVISION OF THE COURTS IN BOSNIA AND HERZEGOVINA AND EFFICIENCY OF THE COURTS
}

\begin{abstract}
The economic aspect of the judicial system functioning in Bosnia and Herzegovina is complex and multifaceted, which implies the existence of not just one reason or narrow economic view on economic and financial possibilities of improving the judicial system. The basis of this view is related to the way in which judges, court officials, and even lawyers and litigants think about the justice system. Too much attention is given to the rules, but not enough to achieving concrete results. Timeliness is underestimated, both in procedural laws, and in the attitudes of people. The subject of this paper is investigating the cause of the inefficiency of the courts and delays in court proceedings, and working out specific principles and recommendations for their elimination, with the minimum expenditure of budgetary funds. The aim is to emphasize the role of human and systemic elements of the judicial system in BiH, as well as highlighting certain guidelines that are relevant to that system. Fair and timely resolution of cases results in high efficiency and good service delivery to the public, which can be emphasized by the fact that it is easy to delegate certain tasks to other staff, but responsibility cannot be delegated.
\end{abstract}

Key words: division of the courts, efficiency of resolving, case management

JEL classification: K23, K29

\section{РАСПОРЕД СУДОВА У БОСНИ И ХЕРЦЕГОВИНИ И ЕФИКАСНОСТ СУДОВА}

\begin{abstract}
Апстракт
Економски аспект функционисања судског система у Босни и Херцеговини је сложен и вишестран, ито импличира постојање не само једног разлога или уског економског погледа на економско-финансијске могућности унапређена судског система. Основа оваквог погледа је везана за начин на који судије, службеници суда, па чак и правници и парничне странке размишьају о правосудном систему. Превише се пажне придаје правилима, а ни близу довољно постизању
\end{abstract}

\footnotetext{
${ }^{1}$ spuric@jura.kg.ac.rs

2 ossudbn@teol.net
} 
конкретних резултата. Правовременост је потиењена, како у процедуралним законима, тако и у ставовима људи. Предмет рада се састоји у истражсивању узрока неефикасности рада судова и кашњења у судским прочесима, односно израђиваьу конкретних начела и препорука за юихово отклањање, уз ито мањи утрошак бучетских средства. Циљ је у апострофирању улоге људских и системских елемената судског система у БиХ, као и истицану одређених смерница које су од значаја за наведени систем. Правично и правовремено ремавање предмета резултира високу ефикасност и добро пружање услуга јавности, ито се може апострофирати тиме, да је лако поједине задатке делегирати на друго особље, али се одговорност не може делегирати.

Кључне речи: распоред судова, ефикасност решавања, управљање предметима

\section{Introduction}

Within Bosnia and Herzegovina (Federation), cantons operate virtually independently, each with a separate Ministry of Justice, which inevitably leads to inconsistencies in the functioning of the courts, which has a negative impact on their efficiency. The human factor and its unambiguous economically functional role in the judicial system emphasize the growing importance, through the timely and efficient delivery of court services.

An efficient court administration requires a functional composition. Divided structure is essentially inefficient and too expensive. In order to find solutions for a more efficient judicial system, there must be a certain consistency and accountability for results at the entity level.

It is necessary to emphasize the role of too restrictive and detailed rules governing the operation of the courts which seriously limit the local discretion of court administration, while ignoring the potential and interests of innovation of any kind within the judicial system. Presidents of courts must have the freedom while managing the court and must be interested in the leadership in such organizations. Competent judicial officers who have certain powers, including the appointed high court administrator to whom the president of the court can delegate administrative duties must be available to the top manager.

Within the economic dimension it is important to emphasize the role of financial resources that determine the reach of functionality of such system. The general lack of resources reduces the functionality of the court administration. The observed economic dimension can be seen from two angles: one is linked to the poor financial position of employees and the other to the poor material base of the judicial system. The work of poorly paid officials in poor material conditions, which are primarily reflected in the poor interior of the work space, poor office equipment etc., directly affect the low productivity in the operation of the courts. Budget funding mechanism is stiff, because it does not allow for transferring funds from one account to another, which would allow a court to operate more efficiently with fewer employees.

As the effectiveness of the work is dependent on funding, so the time is also a limiting factor. Cases that are in the process tend to become a bottleneck, because they last 
for too long while waiting for hearings or other action. Accordingly, case management is another dimension of the economic aspect of improving the judicial system. The judiciary can achieve maximum productivity by managing their cases and their time. Changes in procedural standards can be very important to facilitate the efficient management of cases. Local judicial autonomy should enable the president of the court and other judges to delegate administrative and less judicial tasks to other officials, in order to ensure that their time is used where it is most needed.

\section{Division of the courts in bosnia and herzegovina}

An efficient justice system requires that the courts in the country are divided in a rational and cost-effective manner. Too many courts cause unnecessarily high budgetary allowances, and limited resources are divided into too many units on the field. As a result of the new administrative division into two entities and Brčko District after the war, the structure of the courts has changed, primarily for political reasons, and not for economical reasons or efficiency. In 1989, pursuant to the Law on Courts there were seven high courts in Bosnia and Herzegovina: Banja Luka, Doboj (today Republic of Srpska), Bihać, Mostar, Sarajevo, Tuzla and Zenica (in today's Federation) (“Official Gazette of Bosnia and Herzegovina" number 19/86 and 25/88 and 33/89). Today we have 10 cantonal courts (one in each canton), 5 district courts in RS and one in Brčko District - which makes 16 high courts in $\mathrm{BiH}$.

The network of the courts of general jurisdiction/municipal courts in $\mathrm{BiH}$ includes 52 courts, while $\mathrm{FBiH}$ and RS are considering the establishment of several new ones. Republic of Srpska has 19 courts of general jurisdiction, 5 district courts, 5 district commercial courts, one High Commercial Court and one Supreme Court of the RS. Federation has 32 municipal, 10 cantonal courts and one Supreme Court of the Federation of BiH. Brčko District has one Court of General Jurisdiction and one Appellate Court.

The question of how many courts there should be and where they should be located is an important issue from the standpoint of efficiency - both for high and municipal courts. Too many courts that are too small is not economically justifiable.

The role of judicial authority includes all the duties and obligations that judicial authority should perform in the right way in order to achieve the final goal of efficient, independent and high-quality implementation of judicial authorities. The independence of judges is the foundation of judicial independence, and it is achieved by the manner of election of judges, permanence of judicial office, appropriate financial situation of judges and their social status. Judicial independence means that the court in its operation is bound only by the Constitution and laws, and that it is independent from all types of pressure, especially political.

The judicial authority in Bosnia and Herzegovina is extremely specific. The Dayton Constitution does not envision a classic division of authority in Bosnia and Herzegovina, thus the judicial authority is completely eliminated, except for the Constitutional Court of Bosnia and Herzegovina which has other competences. The Court of Bosnia and Herzegovina was established subsequently because of the fact that there was no court of general jurisdiction at the state level which would function as the supreme court of a state. This fact influenced the very realization of the role of judicial authority. 
Court administration cannot be considered separately from the justice administration as a whole. Funds for the work of the courts, and the conditions in which the courts operate have a direct impact on the efficiency of the courts. In most countries justice administration is carried out by the Ministry of Justice (MoJ) or an independent body. There isn't a Ministry of Justice for the whole of Bosnia and Herzegovina. Federation and RS each have their own ministries, and Brčko District has the Justice Commission, which has a similar role. In addition, each canton in the Federation has its own Ministry of Justice. The Ministry of Justice of a canton carries out the justice administration.

The independence of the courts is one of the basic principles of democracy. However, independence is related primarily to the decisions of the judges. The administrative bodies responsible for the budget are obliged to provide courts with space, equipment for work and salaries that allow for their independence in performing their duties. On the other hand, budgetary bodies have the right to request from the courts to use budget funds in an efficient way.

Regular analysis of the court network is necessary to ensure uniform delivery of judicial services in the whole territory of the Federation of Bosnia and Herzegovina and the Republic of Srpska. In its role of an advisor, a ministry of justice passes standards, guidelines, provides training, IT equipment and other support to the courts. From the standpoint of cost-effectiveness of using funds, not each court should be responsible for the development of their own systems and operating methods. This is obvious when one thinks of the future computerized case management system. Ministries of justice should also be responsible, jointly working with the courts, for the initiation and developmentz of adequate resources for operation. MoJ should also be in the focus of legislative initiatives, and for the overall operation of the courts, ministry of justice can serve as a source of expertise and a forum for discussion of all matters of interest to the judiciary.

The political structure of the Federation makes justice administration unnecessarily expensive in this entity. Administrative responsibility for the courts is fragmented between ten separate cantons with ten separate ministries of justice. In some of these cantons there are only one to three municipal courts. In this situation, it may be difficult for different cantonal ministries of justice to develop and provide the necessary level of support and knowledge, especially in terms of justice administration. The resources are very limited in most of these cantons and courts receive different levels of support and services from different ministries.

It could be said from several aspects that there is a need for a single court system in the Federation. Books of Rules of the courts are used to write the rules, training programs and for the exchange of experiences and knowledge among the courts (Book of Rules on Internal Court Operations "Official Gazette of $\mathrm{BiH}$ " no. 57/08, 66/12, and Book of Rules on Internal Court Operations "Official Gazette of the Republic of Srpska" no. 09/14). The budget process and reporting system are two other areas where the single system would be beneficial for the entire Federation.

In order to improve efficiency and because of the unity of the system, there is a need for the justice administration which would be more centralized, at least at the entity level. The question of whether this centralized administration should be run by the Federal Ministry of Justice or, as in Brčko, an independent body, is not relevant from the standpoint of efficiency.

If because of the politics it is not possible to centralize executive authority of the courts in the Federation, then it is more important than ever to achieve close cooperation 
between cantonal ministries of justice. The Federal Ministry of Justice is in a position to coordinate the different cantonal ministries of justice, exchange information about what is happening in certain courts, and to make it easier - as much as possible - to create a single standard of operation of the justice in the entity.

In Bosnia and Herzegovina there are a number of factors that slow down the realization of high-quality, efficient and independent role of the judicial authority, which are the result of the current transition of the country. Given that Bosnia and Herzegovina is a complexly arranged country and that it aspires to join the European Union, it is of elementary importance to adequately regulate relations of all three levels of government, especially because the European space will become a single economic and legal area, with the final aim of efficient implementation of human rights and freedoms.

\section{Efficiency of courts in bosnia and herzegovina}

\subsection{Court Administration}

Result of efficiency is characteristic for the functioning of public institutions. When it comes to the court administration, the books of rules confirm the important role of a president of a court in the administration of the court by giving them a lower out-turn or they do not work on the cases at all (depending on the size of the court). In the election of the president of the court, it is important to find a person who, in addition to the fulfilment of conditions for the election of judges, has the skills and interest in management. Alternative election procedures that would take into account management skills should be considered, so that the appointment is done by non-political, judicial institution, as in many other European countries (Lukić 2000, 57).

If the court has a case backlog, the president of the court is obliged to issue a work plan in order to resolve the backlog. This may involve lobbying the Ministry or the legislative authorities for additional funding, re-routing resources of the court, or establishing priorities, inter alia, to resolve the backlog. In one court, the president of the court has asked each judge to report on the status of all cases older than three years providing an explanation of why these cases are so slow to resolve and suggestions for resolving them. Not only did the president of the court in this way came to a certain knowledge, but it served to introduce a certain responsibility and achieve motivation of judges (Sadiković 2009, 27). If the problem is not knowledge of the judges, but their willingness to work, the president of the court may resort to other methods. In the Federation and the Republic of Srpska, president of a court has the authority to start disciplinary procedures against judges who neglect their duties. President of a court should not hesitate to use these procedures when a judge deliberately does not fulfil the work obligations and refuses to resolve this problem (European Commission for Democracy through Law 2010).

The most important element in the work of a president of a court is that he/she acts as the "owner" of the court, with all the challenges that go with it. Court presidents who are struggling with a lack of funds resources (money, judges, staff, equipment, work space), may be tempted to use it as an excuse, and wash their hands of responsibility for the problems and failures of their courts. Although lack of resources is a significant 
problem, president of a court is required to seek solutions to these problems as best he/she can, and to extract the maximum benefit from the resources at his/her disposal (European Commission 2013, 23).

In addition to deciding cases, judges in Bosnia and Herzegovina are also responsible for other administrative tasks. This includes, inter alia,supervising the land registry and the registry of business entities. In other legal systems, these tasks are performed by other ministries of the government and there is no particular reason for these jobs to remain within the judicial function (Leskovac, 2009, 545). Aims to improve the efficiency of the court may be:

- better organization of the court,

- better cooperation between the court departments,

- $\quad$ avoiding periodic work inefficiency,

- improving flexibility in the use of court staff,

- $\quad$ increasing efficiency in dealing with the influx of cases (e.g. specifically set a goal to reduce the number of hearings between the first hearing and the main hearing to an average of up to a specific day),

- improve the promptness (e.g. determine a goal to reduce the average time for resolving civil cases from 16 months to 10 months by a certain day next year),

- $\quad$ plan to reduce the case backlog (for example, set a goal to reduce the case backlog by $35 \%$ by a certain day next year),

- use of the possibilities that certain tasks of the judges are redirected to court staff,

- avoiding unnecessary procedures,

- improving service to the public,

- $\quad$ establishing standards of service,

- $\quad$ improvement of working conditions (BiH 2009 Progress Report).

A more direct issue for the efficiency of the courts is almost inevitable misallocation of resources which are eventually granted. The budget adopted for each court is divided into categories, and the courts generally do not have the right to transfer funds from one category to another according to the priorities and most urgent needs of the court. Most of the budget is used for court staff, and most of the funds are used for salaries of judges and staff. Structure of staff in court is determined by the old and inflexible rules, which do not necessarily reflect the reality of the court operation. These rules should be amended so that the courts could use the staff in a more efficient and productive way. The courts also have to use more of the existing possibilities to redistribute the existing staff in order to resolve the most urgent needs of the court. The courts could, if allowed, reorganize their staff so they hire more associates and cut staffing in less critical areas as appropriate. Of course, this scenario with associates only serves as an example (Consultative Council of European Judges on the funding and management of courts 2012, 35). Court administration of each court must ensure keeping accurate all necessary records on the work of judges and legal officers. A set of ways of completing cases within a certain department and the value of these cases is established within the existing court departments defined by the Book of Rules of Court Operations and Book of Rules of the system for automatic case management in the courts for each type of case.

Presidents of the courts of general jurisdiction, cantonal/district courts, district commercial courts, the High Commercial Court in Banja Luka and the Appellate Court 
of Brčko District of Bosnia and Herzegovina, aside from the job of a president of the court, must work directly on cases and achieve the following: in the courts with up to 6 judges and legal associates (with a secretary of a court) $70 \%$ of out-turn required by the Book of Rules, in the courts with up to 6 judges and legal associates (without a secretary of a court) $50 \%$ of out-turn required by the Book of Rules, in the courts with 7 to 13 judges and legal associates (with a secretary of a court) $50 \%$ of out-turn required by the Book of Rules, in the courts with 7 to 13 judges and legal associates (without a secretary of a court) $40 \%$ of out-turn required by the Book of Rules, in the courts with 14 to 20 judges, $30 \%$ of out-turn required by the Book of Rules, in the courts with over 20 judges and legal associates, presidents should not work on cases, except where provided otherwise by a special decision or instruction of the HJPC (Article 14 of the Book of Rules on Orientation Measurements for Performance of Judges, Legal Associates and Other Court Employees in Bosnia and Herzegovina, "Official Gazette of BiH", number 2/14).

The work of judges, legal associates and presidents of courts who work on cases in the manner prescribed by book of rules is monitored and evaluated through the rules on out-turn realization, as well as records on the number, type and manner of completion of completed cases. At the end of the reporting period, work results are calculated based on the data from the CMS. If a judge or a legal associate worked on several different cases aside from their own during the reporting period, before calculating work results it is necessary to make the conversion and calculation of standards of all cases to the standard of primary cases of a judge or a legal associate. HJPC of $\mathrm{BiH}$ continuously works on finding optimal solutions for the organization of work processes in the judiciary, in order to achieve greater efficiency, timeliness and quality of the work of the courts, with special emphasis on the creation of conditions for more efficient resolution of cases in courts.

\subsection{Case Management}

President of a court is responsible for the total number of cases in court, starting with responsibility for the distribution of cases to judges (United Nations Office on Drugs and Crime, 2010, 19). However, each judge is required to manage cases well, without interference from the president of the court. President of a court, on the other hand, has a general duty to ensure that all cases are resolved within a reasonable time, and, if necessary, resolve the problem of case backlog by redistribution of cases or by using other methods. The cases should be allocated to judges as soon as possible, preferably on the same day when they are received. As already being done in most courts, cases should be distributed on the basis of random selection. The system must be transparent in order to avoid possible manipulation or even the semblance of manipulation. When strictly automatic system of random selection is established, then it can be controlled by staff, without further interference by the court president.

New judges often take cases from judges who have left earlier. Sometimes a judge is allowed to give a certain number of his/her cases to new judges and in this case they are given the oldest and most complicated cases. The court president should ensure that the new judge is not burdened disproportionately by large number of such difficult cases. Since the new judges are typically inexperienced, they should be given time for education, to work on reduced number of cases or for some time, for example three months, to work only on simpler cases (United Nations Office on Drugs and Crime 2010, 21). Hearings 
should be scheduled at the earliest possible stage of case management. Inspection of the cases showed that, except for a few exceptions, courts generally schedule the first hearing quite early in the process of case management. Settlements in the early stages of the process have a lot of advantages. The settlement saves money to the parties, as well as time and mental and emotional burden of litigation. The settlement often leads to a solution which is more beneficial for both parties, as it will inevitably be more sensitive to the interests of the parties than a court decision. Settlements in the early stages of cases are also beneficial to the courts, because in that way courts use fewer resources.

Judges in Bosnia and Herzegovina are already familiar with the settlement hearings. Mediation could have a more systematic form in which a neutral intermediary helps the parties to find their own resolution of a dispute. The mediator helps the parties to identify the issues on which they disagree, facilitates discussion and helps the parties to find a solutions based on their fundamental interests. Mediation by judges is proposed as a mandatory part of civil proceedings in Brčko District. Mediation was also considered by the Work Group working on the new Law on Civil Procedure. Mediation by judges is useful for parties, as it can be done without additional cost. However, the judge who had the role of a mediator in the same case will not be able to pass a judgement. If a resolution cannot be reached through mediation, the case should normally be transferred to another judge.

Mediation by lawyers and other people trained in mediation is common in many countries. Then the parties have a choice of mediation, even before going to court. The courts may recommend mediation by a lawyer, but in the absence of volunteer offices for mediation, the parties usually have to pay a mediator themselves. The combination of court mediation and by a lawyer is one of the possibilities. These alternatives should be considered when writing the new Law on Civil Procedure (Judicial Reform and Government Accountability 2012, 27). Mediation skills and dispute resolution skills must be learned. Some training of judges and lawyers in the mediation has already been done. However, if mediation becomes a part of the Law on Civil Procedure, training on mediation will be needed for judges and lawyers in the whole country.

\subsection{Resolving the case backlog}

Resolving the issue of the case backlog in the courts of Bosnia and Herzegovina is the burning issue of the judiciary and other relevant institutions in Bosnia and Herzegovina. In 2002 this issue was identified as "one of the main issues in the justice system of Bosnia and Herzegovina" in a comprehensive report on the state of the judiciary in Bosnia and Herzegovina "Justice at the right time", prepared by the Independent Judicial Commission in preparation for the comprehensive reform of judiciary in this country. It was concluded that "the existence of a large number of pending cases is not only the result of court inefficiency; it can also be the cause of inefficiency". Unfortunately, the problem of case backlog is a major obstacle to the establishment and development of efficient judiciary and confidence of citizens in the judicial system of Bosnia and Herzegovina, because the case backlog increases every year.

Thus, the Annual Report on the work of the Council for 2014 presented a detailed analysis of statistical indicators which showed a negative trend which will probably continue in the period to come, especially in relation to the dynamics of inflow and 
resolving the so-called utility cases, as outlined in one of the many initiatives of the High Judicial and Prosecutorial Council (HJPC) that all relevant factors in society are to tackle the problem of case backlog and contribute to solving a problem which is not exclusively a problem of judiciary.

According to the annual report of the HJPC for 2013, more than 50\% of pending cases in the courts of Bosnia and Herzegovina is older than a year, while $9 \%$ of pending cases were initiated more than five years ago, but are still unresolved. In recognition of this problem, and bearing in mind that the slow resolution of court cases may constitute a violation of human rights under Article 6 of European Convention on Human Rights, which proclaims the right of individuals to a fair trial within a reasonable time, the HJPC adopted the "Guidelines for developing a plan to resolve old cases according to age of the initial document" in December 2010. It is important to note that the age of the cases is determined according to the age of the initial document, that is according to the time that a party to the proceedings is waiting to have their case decided. The key criterion that puts an obligation before the president of a court to draw up a plan for resolving old cases is a three-month out-turn of old cases per judge, taking into account the provisions in accordance with which certain cases are considered old, and as prescribed by the Guidelines.

In accordance with the Guidelines, out of 73 courts that exist in Bosnia and Herzegovina, 53 regular courts have taken the obligation of drawing up a plan for resolving old cases involving a total of 119,040 old cases, which should be resolved during 2014. It is noteworthy that 19 courts in $\mathrm{BiH}$, in accordance with the Guidelines, did not have the obligation of drawing up a plan to resolve old cases for 2014, meaning that these courts are up to date in their operation.

The initial plan to resolve old cases according to their age for 2014 included 119,040 cases. In the period from $1^{\text {st }}$ January 2014 to $31^{\text {st }}$ March $2014,19 \%$ of the plan was implemented (with the aim of achieving 100\% implementation of the plan by the end of the year), and the average achieved approximate out-turn of judges to resolve old cases was $36 \%$. The judges who drew up plans for resolving old cases are expected to achieve at least $40 \%$ annual estimated quotas by resolving old cases.

Activities of HJPC and the courts in 2014 were specifically aimed at improving the work of the courts by increasing the productivity of their work, thus reducing the number of pending cases. The result of these activities is that in 2014 a positive trend continued in increasing the productivity of the courts through applying the Book of Rules on Orientation Measurements for Performance of Judges and Legal Associates in Courts in $\mathrm{BiH}$ (Book of Rules on Orientation Measurements) and in reducing the number of non-utilities cases by $10 \%$, which represents a reduction of 43,443 cases compared to the end of the previous year. 
Table 1. The case backlog in courts

\begin{tabular}{|l|c|c|c|c|}
\hline Courts & 31 Dec 2011 & 31 Dec 2012 & 31 Dec 2013 & 31 Dec 2014 \\
\hline The Court of BiH & 3635 & 3765 & 2867 & 2694 \\
\hline The Supreme Court of the FBiH & 3276 & 3638 & 6568 & 8260 \\
\hline The Supreme Court of the RS & 1648 & 1758 & 2012 & 2554 \\
\hline The Appellate Court of Brčko District & 610 & 558 & 440 & 322 \\
\hline The High Commercial Court in Banja Luka & 277 & 223 & 223 & 294 \\
\hline Cantonal courts & 30922 & 32905 & 38136 & 44635 \\
\hline District courts & 5951 & 6492 & 6201 & 6457 \\
\hline District commercial courts & 15136 & 14133 & 13135 & 11029 \\
\hline Municipal courts & 279676 & 273454 & 269097 & 230302 \\
\hline Courts of general jurisdiction & 119812 & 111638 & 103052 & 92634 \\
\hline $\begin{array}{l}\text { Court of general jurisdiction of Brčko } \\
\text { District }\end{array}$ & 10014 & 9140 & 8084 & 7191 \\
\hline Total & 470957 & 457704 & 449815 & 406372 \\
\hline
\end{tabular}

If we look from the point of realization of out-turn, the productivity of judges and legal associates in courts increased by $7 \%$ compared to the previous year, which represents an overall increase in productivity of the courts by $7 \%$ compared to the period before the application of the Book of Rules on Orientation Measurements ("Official Gazette of $\mathrm{BiH}$ ”, number 43/12). Although the implementation of the Book of Rules on Orientation Measurements showed excellent results, the HJPC will monitor and analyse the effects of the application of the Book of Rules on Orientation Measurements, and will, together with representatives of the judicial community work on its improvement with the aim of increasing the efficiency of the judiciary and better access to justice for all $\mathrm{BiH}$ citizens.

Thanks to the implementation of plans the courts resolve over 70,000 of the oldest cases every year. In 2014, the courts resolved 85,941 cases thanks to plans, which represents the increase in the number of planned resolved cases by $16 \%$ (13,625 cases) compared to 2013.

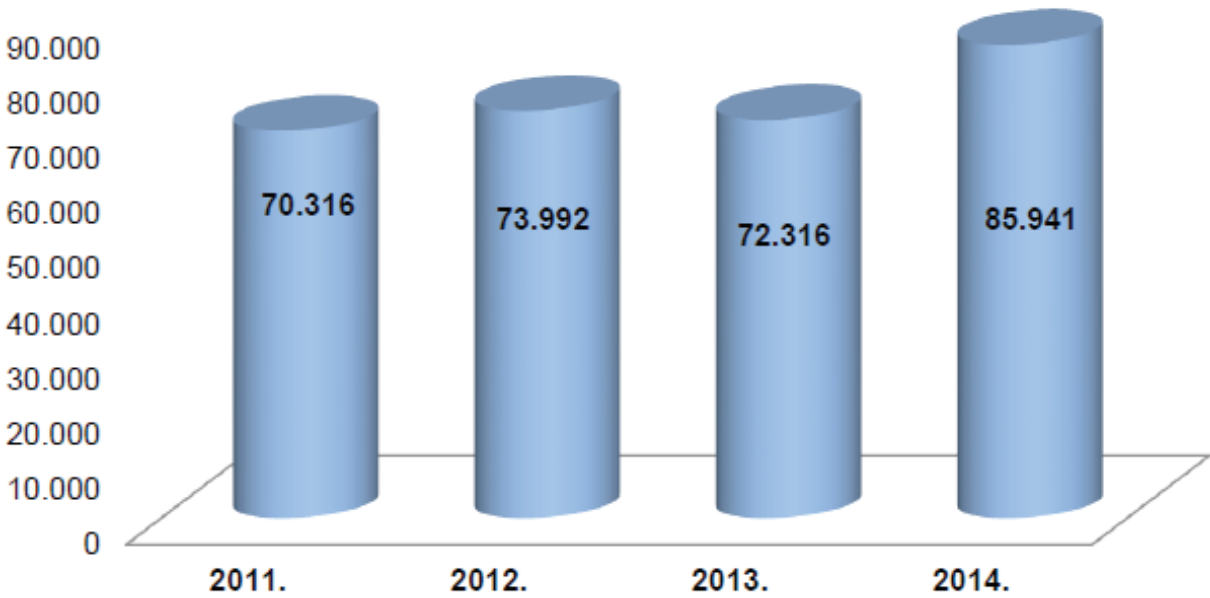

Graph 1. The trend of resolving cases in plans over the years 
In addition to reducing the number of pending cases in courts, the HJCP paid special attention to the analysis of the proceedings length in 2014. To this end, since 2012, the HJCP has been implementing the Book of Rules on Timeframes for acting in cases before the Courts and Prosecutors' Offices in $\mathrm{BiH}$ ("Official Gazette of $\mathrm{BiH}$ ", number 5/13, 101/13 and 61/14). The Book of Rules defines optimal and predictable deadlines for acting in cases.

\section{Conclusion}

There are many reasons why the judicial authority in Bosnia and Herzegovina is in a specific position. But we can safely say that the judiciary in Bosnia and Herzegovina has failed in realization of its role in an efficient and effective way. There are many reasons for this: lengthy court proceedings, a large number of pending cases, insufficient number of judges, poorly paid judges, corruption, low level of computerization, poor communication between the media and the judiciary, rare initiation of disciplinary proceedings against judges and prosecutors. The absence of a Supreme Court at the state level, which would harmonize judicial practice of regular courts and ensure the equality of all citizens before the law, is another reason why the judicial authorities in Bosnia and Herzegovina are not achieving their role well.

The judicial system of Bosnia and Herzegovina is burdened by a large number of pending cases and this is an important issue that must be resolved. Case backlog and delays in proceedings lead to the loss of confidence in those using the court system, because it seems that justice is unavailable. This situation negatively affects even the judges. The main reasons for delays in court proceedings are corruption, inefficient practices in the management of the court, inadequate legislation and lack of competent judges. Although a positive trend in the quality and quantity of work has been recorded, even in reducing the case backlog, there are still about two million (mainly utility) unsolved old cases in the whole of Bosnia and Herzegovina. Resolution of case backlog is a burning problem of judicial institutions in Bosnia and Herzegovina. High Judicial and Prosecutorial Council of Bosnia and Herzegovina and the Ministry of Justice of Bosnia and Herzegovina have adopted an action plan to reduce the case backlog in courts.

As a result of continuous inflow of new cases and the case backlog, there is a problem of insufficient number of judges. In addition to the number of judges, the problem is also the manner of their election, their training and the lack of permanent forms of training, for example in the field of ethics. In some countries there is a periodic evaluation of judges in order to assess their expertise and to assist them in further education. All this contributes to the development of professional and ethical judiciary which is the cornerstone of the rule of law.

Also, poor communication between the media and the judiciary influences the efficiency of the exercise of judicial authority. It is necessary to establish a balance between the needs of the public for specific information and to ensure the regularity of court proceedings. Initiation of disciplinary proceedings against judges and prosecutors contributes to accountability and transparency, and they are the basis for gaining confidence of the public in the judicial system. In order to initiate disciplinary procedures more often (when necessary), the public should be informed about the role of judges. The public must be informed about the standards expected of a judge. When the public 
is better informed about the measures to ensure accountability, the public will have more confidence in judicial institutions.

It is a unique situation in the comparative constitutionality, according to which the judicial authority in Bosnia and Herzegovina has been reduced to the Constitutional Court of Bosnia and Herzegovina. This court also has a part of its jurisdiction which is characteristic of the highest judicial instances in some complex countries, but it is not the supreme court of the country. Constitutional courts usually do not belong to the judicial authorities, because it does not resolve classic legal disputes, but are competent to control the constitutionality and legality. In Bosnia and Herzegovina, it is necessary to establish a judicial system with the Supreme Court of Bosnia and Herzegovina at the top.

It would be extremely useful if the supreme court existed. There is a substitute which compensates for the lack of a Supreme Court to some extent, and it is so-called appellate jurisdiction of the Constitutional Court of Bosnia and Herzegovina. So, when it comes to protecting human rights and freedoms, if entity courts pass a final decision and a citizen, if he/she is dissatisfied with the decision, may appeal to the Constitutional Court of Bosnia and Herzegovina and so far it has worked in many cases to protect individual rights and contributed to the harmonization of judicial practice. However, unfortunately, it does not cover all relations of the judiciary, such as civil relations, economic relations and similar. For that there should be a supreme court, like in other countries which would have a task to harmonize the judicial practice in the entire territory of Bosnia and Herzegovina and to work on equality of all citizens.

\section{References}

Evropska komisija za demokratiju kroz pravo (Venecijanska komisija), „Mišljenje o ustavnoj situaciji u Bosni i Hercegovini i ovlaštenjima Visokog predstavnika“, CDL-AD, 2010.

Izveštaj o napretku Bosne i Hercegovine u 2009. godini, Saopštenje Komisije evropskih zajednica Evropskom parlamentu i Veću/Savetu, Brisel, 14. oktobar 2009., SEC (2009) 1338.

Judicial Reform And Government Accountability, Bolje upravljanje predmetima za efikasnije sudove, Projekat za reformu pravosuđa i odgovornu vlast, Beograd, 2012.

Leskovac, S., Politika reforme državne uprave zemalja u tranziciji, s posebnim osvrtom na Bosnu i Hercegovinu, Sarajevo, 2009.

Lukić, R., „Raspodela nadležnosti između zajedničkih institucija Bosne i Hercegovine i entiteta“, Zbornik radova sa naučnog skupa u organizaciji Akademija nauka i umetnosti Republike Srpske, Banja Luka, 2000.

Mišljenje broj 12. Konsultativnog veća evropskih sudija o finansiranju i upravljanju sudovima, sa osvrtom na efikasnost pravosuđa i na član 6. Evropske konvencije za zaštitu ljudskih prava i osnovnih sloboda, Strazbur, 2012.

Nezavisna pravosudna komisija Bosne i Hercegovine, Pravda u pravo vreme, Izveštaj Projekta reforme sudske uprave, Sarajevo, 2002. 
Pravilnik o orijentacionim merilima za rad sudija, stručnih saradnika i drugih zaposlenih u sudovima u Bosni i Hercegovini, (,,Službeni glasnik BiH“, broj 2/14).

Pravilnik o unutrašnjem sudskom poslovanju (,Službeni glasnik BiH“ br. 57/08, 66/12)

Pravilnik o unutrašnjem sudskom poslovanju (,Službeni glasnik Republike Srpske“ br. 09/14)

Pregled sistema pravosuđa i statistike - „Integralni registarski broj predmeta i upotreba elektronskog sistema za upravljanje predmetima, i implikacije za statističke podatke“, u okviru Projekta: EU, United Nations Office on Drugs and Crime, Razvoj instrumenata monitoringa za pravosudne i policijske institucije Zapadnog Balkana 2009-2011., Sarajevo, 2010.

Sadiković, Ć., „Za državu novog stoljeća - Bosna i Hercegovina kao savremena demokratska država“, Fond otvoreno društvo Bosne i Hercegovine, 2009., Projekat pod naslovom „Ustav Bosne i Hercegovine - ka novim rešenjima“, 16. novembra 2009.

Specifična iskustva novog pilot prikupljanja podataka u Bosni i Hercegovini, 2010. godine, u okviru Projekta: EU, United Nations Office on Drugs and Crime, Razvoj instrumenata monitoringa za pravosudne i policijske institucije Zapadnog Balkana 2009-2011., Sarajevo, 2010.

Ured koordinatora reforme javne uprave, Sistemski pregled javne uprave - Završni izveštaj, ECO Evropska Komisija, Sarajevo, 2013.

Visoko sudsko i tužilačko veće Bosne i Hercegovine, Godišnji izveštaj za 2014. godinu, Visoki sudski i tužilački savet Bosne i Hercegovine, Sarajevo, 2015. 